\title{
Study on NPK Performance in Food Waste Composting by Using Agricultural Fermentation
}

\author{
Siti Noratifah Jamaludin ${ }^{1}$, Aeslina Abdul Kadir ${ }^{2, *}$, and Nur Wahidah Azhari ${ }^{1}$ \\ ${ }^{1}$ Department of Environmental Engineering and Water Resources, Universiti Tun Hussein Onn \\ Malaysia (UTHM) 86400 Parit Raja, Batu Pahat, Johor, Malaysia. \\ ${ }^{2}$ Associate Professor, Department of Environmental Engineering and Water Resources, Universiti \\ Tun Hussein Onn Malaysia (UTHM) 86400 Parit Raja, Batu Pahat, Johor, Malaysia.
}

\begin{abstract}
Food waste represents almost $60 \%$ from the total municipal solid waste disposed in the landfill. Alternative disposal method for food waste could be conducted by using composting method. In this study, investigationon food waste composting by using agricultural fermentation was carried out to find out the performance of the compost. Two types of compost were produced which were commercial compost and research compost and total of 8 reactors were tested during this study. Research compost consist of coconut fiber (decomposing medium) and the combination of salt and breadfruit peels as the fermentation liquid, while rice husk was used as decomposing medium for commercial compost along with fermented soybeanand brown sugar as fermentation liquid. Physical and chemical parameters which are temperature, $\mathrm{pH}$ value, moisture content, Total Nitrogen $(\mathrm{N})$, Total Phosphorus (P) and Potassium (K) concentration were determined. Based on the results of 20 weeks composting, the overall temperature range from $27{ }^{\circ} \mathrm{C}$ to $45{ }^{\circ} \mathrm{C}$ which shown the active phase for composting occurred. On the other hand, during the period of composting, most of the $\mathrm{pH}$ value in each reactor is above 5 and approximately at neutral. This shown that the microbial respiration in the composting reactor was inhibited and had approached the mature phase. As for NPK content, Total Nitrogen value range from $98 \mathrm{ppm}$ to $2268 \mathrm{ppm}$ for commercial compost, while $84 \mathrm{ppm}$ to $2240 \mathrm{ppm}$ for research compost. Total Phosphorus has the values of $0.871 \mathrm{ppm}$ to 11.615 ppm for commercial compost and $1.785 \mathrm{ppm}$ to $14.143 \mathrm{ppm}$ for research compost. On the other hand, result for potassium is from $91.85 \mathrm{ppm}$ to $645.55 \mathrm{ppm}$ for commercial compost and from $133.95 \mathrm{ppm}$ to $686.2 \mathrm{ppm}$ for research compost. As a conclusion from the results obtained, the compost in this study is sufficient to be use for agricultural purposes and the best performance of NPK value was demonstrated by Reactor C2 from research compost.
\end{abstract}

*Correspondingauthor: aeslinaabdulkadir@gmail.com 


\section{Introduction}

The issue of food waste are now starting to become a regional concern even for developed countries that are more likely to find the best management methods along with other solid waste. Countries such as Korea and Japan has been practicing the separation of food waste from other solid waste due to the breakdown of food waste, lack of landfill space, transport issue and disposal of food waste problem that also occurs in many combustion processes [1].

In Malaysia, the solution is sought to solve the problem of solid waste management based on the concept of environmentally acceptable to the public. There isstill a nonexistentof food waste separation in Malaysia but the solutions for this matter need to be resolved immediately because food waste accounts for $65 \%$ of municipal solid waste [2]. The total generation of food waste is a major cause of many problems associated with the landfill, such as odor, leachability of toxic, and greenhouse gas emissions [3].

Food waste recycling in Malaysia is rarely implemented. There are several options for implementing the method of recycling food waste. One of the option were implemented by few countries including Germany and Britain [4] that perform the anaerobic decomposition by nurture methane gas to be used as fuel. Another option is the composting method.

Composting are the process of decomposition and stabilization of organic materials in biology under controlled conditions to produce a final product that can be applied to land without adverse effect to the environment. Microorganisms play an important role in this process. It decompose organic materials to make it a more stable material called compost.

The purpose of this research is to determine the performance of nutrient which are Total Nitrogen $(\mathrm{N})$, Total Phosphorus $(\mathrm{P})$ and Potassium $(\mathrm{K})$ by utilizing agricultural fermentation liquid (research compost) and commercial fermentation liquid (commercial compost)also determine the temperature and the $\mathrm{pH}$ of the compost.

\section{Materials and Method}

\subsection{Preparation of fermentation liquid}

There are two types of fermentation liquid prepared in this study which are using bread fruit peels and salt for research fermentation liquid and using fermented soybean and brown sugar for commercial fermentation liquid. By using Takakura Composting Method three liters of water was mixed with 250 gram salt and bread fruit peel or 250 gram brown sugar and fermented soybean. Fermentation should take no longer than 7 days. It should be done around 3-5 days. During the fermentation process, the lid of the bottle should be loosened once a day to remove the gas that trapped in the bottle. The sweet and sour smell produced indicates that the fermentation liquid has been successfully conducted.

\subsection{Preparation of decomposing medium}

There are also two types of decomposing medium prepared in this study which are using rice husk with soil (commercial decomposing medium) and coconut fiber with soil (research decomposing medium). The ratio for the decomposing medium should be 2 to 1 with soil and rice husk or soil and coconut fiber also using Takakura Composting Method. After mixing the medium with the right ratio, the prepared fermentation liquid was added to the medium with the right amount and then homogenously mixed. The mixture should able to form without liquid dripping. 


\subsection{Preparation of the reactors}

Eight reactors were set up, with 4 reactors each for commercial compost and research compost. For each set, one reactor acted as control while the rest were fed with 500 grams of different types of food waste which are classified as processed food waste, raw food waste and combination of processed and raw food waste. Table 1 shows the feeding of each reactor use in this study.

Table 1. Reactors with different types of food waste.

\begin{tabular}{|c|c|c|c|}
\hline Compost Type & Reactor & $\begin{array}{c}\text { Classification food } \\
\text { waste }\end{array}$ & Types of food waste \\
\hline \multirow{4}{*}{$\begin{array}{l}\text { Commercial } \\
\text { Compost }\end{array}$} & $\mathrm{X} 1$ & Control & - \\
\hline & $\mathrm{A} 1$ & Processed food waste & Candy + chips \\
\hline & B1 & Raw food waste & $\begin{array}{l}\text { Banana peel }+ \text { tapioca peel }+ \\
\text { bread fruit peel }+ \text { coconut husk }\end{array}$ \\
\hline & $\mathrm{C} 1$ & $\begin{array}{l}\text { Processed food waste } \\
+ \text { Raw food waste }\end{array}$ & $\begin{array}{c}\text { Candy }+ \text { chips }+ \text { tapioca peel }+ \\
\text { banana peel }+ \text { bread fruit peel }+ \\
\text { coconut husk }\end{array}$ \\
\hline \multirow{4}{*}{$\begin{array}{c}\text { Study } \\
\text { Compost }\end{array}$} & $\mathrm{X} 2$ & Control & - \\
\hline & $\mathrm{A} 2$ & Processed food waste & Candy + chips \\
\hline & B2 & Raw food waste & $\begin{array}{l}\text { Banana peel }+ \text { tapioca peel }+ \\
\text { bread fruit peel }+ \text { coconut husk }\end{array}$ \\
\hline & $\mathrm{C} 2$ & $\begin{array}{l}\text { Processed food waste } \\
+ \text { Raw food waste }\end{array}$ & $\begin{array}{c}\text { Candy }+ \text { chips }+ \text { tapioca peel }+ \\
\text { banana peel }+ \text { bread fruit peel }+ \\
\text { coconut husk }\end{array}$ \\
\hline
\end{tabular}

\subsection{Parameters Measurement}

Total Kjeldahl Nitrogen (TKN) was used to analyze the concentration value of total nitrogen $(\mathrm{N})$ and Discrete Analyzer (DA) was used to analyze total phosphorus (P) concentration. On the other hand, Atomic Absorption Spectrophotometer (AAS) was used to get the concentration of potassium $(\mathrm{K})$. According to method in APHA Water and Wastewater, $\mathrm{pH}$ meter was used to measure the $\mathrm{pH}$ value of the reactor every week whether it is acid or alkali and thermometer was used to measure temperature everyday.

\section{Result and Discussions}

\subsection{Temperature}

Temperature is the main parameter that controls microbial activity during the composting process. The temperature of each reactor were measured before disposing any food waste into the reactor. The highest temperature determine in this study average between $42^{\circ} \mathrm{C}$ to $45^{\circ} \mathrm{C}$. The increase of temperature during the composting procedure is due to the high temperature generated by the microorganisms through respiration activities and decomposition of organic materials. The temperature of composted matter determines the rate of many biological processes and plays a basic role in microorganism succession understood as a change in the quantitative and qualitative composition of microorganism population [5]. 
Temperature changes during composting process occurs in three stages: the mesophilic, termophilic and curing stages (cooling stage) [6]. In the termophilic stage, microbes are active until the compost reaches a certain stage of decomposition. Then, the temperature will drop to the initial temperature during the cooling stage. The temperature decreased during the composting process for each reactor in commercial and research compost. The beginning of the composting process can be observed in the mesophilic phase, and in a few weeks, the temperature increased until it almost reached to the termophilic phase. When the temperature reaches $40{ }^{\circ} \mathrm{C}$ to $50{ }^{\circ} \mathrm{C}$, both phase microorganism takes place [7]. It is the active phase of composting. Based on the temperature the most active reactor was reactor A1 and A2 that contain process of food waste (chips and coconut candy) for both commercial and research compost. This explains the findings that the microorganisms can withstand one extreme environmental factor, or which is high temperature[8].

Based on the temperature at week 20, every reactor had almost achieved the curing stage. The compost maturation phase begins when the compost temperature falls to the ambient air temperature. Fig. 1 shows the temperature value for both commercial and research compost.

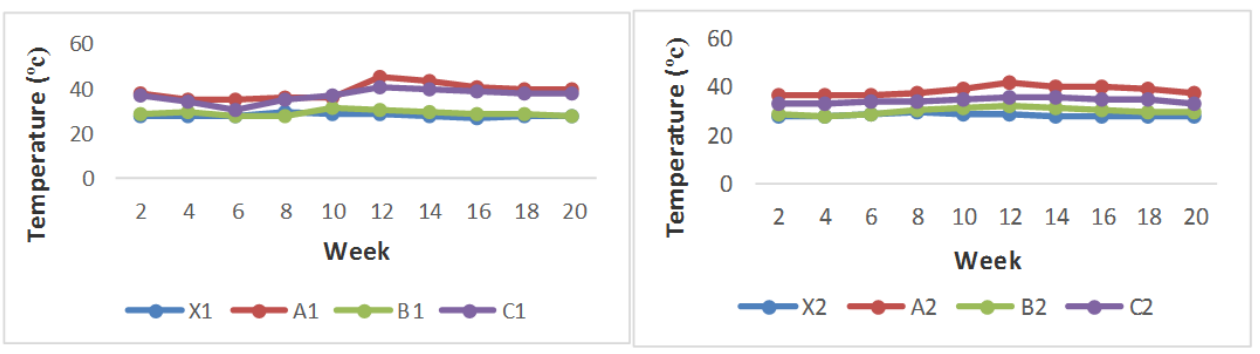

Fig.1.Temperature value for all 8 reactors

\section{$3.2 \mathrm{pH}$}

During the initial stages of decomposition, organic acids are formed. The acidic conditions are favorable for growth of fungi and breakdown of lignin and cellulose. As composting proceeds, the organic acids become neutralized, and mature compost generally has a $\mathrm{pH}$ between 7 and 8 [9]. Fig. 2 shows that all the compost reactor except the raw food waste reactor were acidic in their early process which is the mesophilic phases.

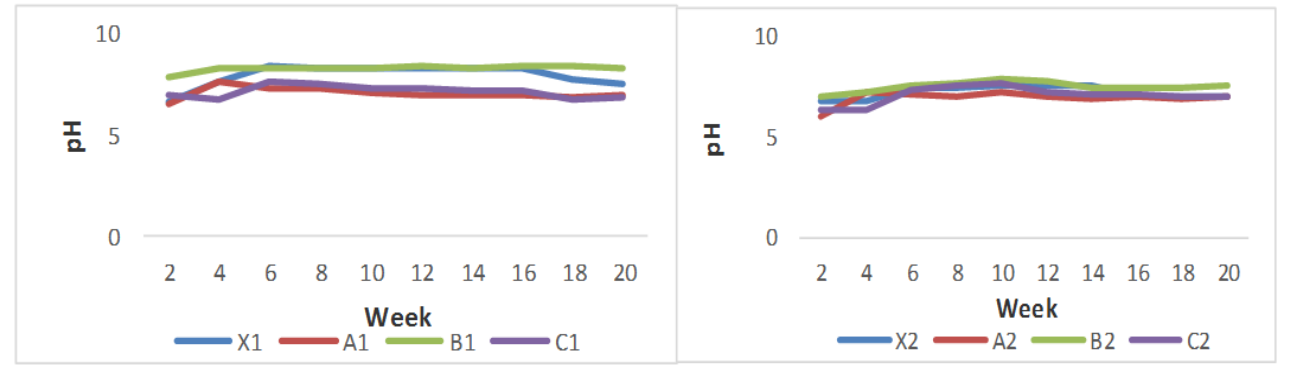

Fig.2. $\mathrm{pH}$ value for all 8 reactors.

In general, in the composting process, the $\mathrm{pH}$ falls below neutral in the beginning due to the formation of organic acid and later rise above neutral because the acids are consumed[10]. The $\mathrm{pH}$ increased around in the 6th week, when the composting process entered its thermophilic phase and slightly decreased in some reactor and become almost 
neutral ( 7 to 8 ) during the 8 th week, when the compost reached its mature state. Moreover, Cooperband [11] stated that optimum $\mathrm{pH}$ value for composting (matured) is between 7 and 8. In this study, food waste that used in each reactors does not effect much in term of $\mathrm{pH}$ because the control reactor has almost the same trend line with other sample reactors.

\subsection{Total Nitrogen Concentration}

In all the reactors, total nitrogen increased slightly during the first four weeks and it increased gradually until week 20 in all compost reactors except for control reactor in both type of compost. Total nitrogen began to rise due to loss of dry mass in terms of carbon dioxide emissions, water loss by evaporation and activities of nitrogen fixing bacteria. The increased in total nitrogen content after 20 days of composting which indicated it might have been due to net loss of dry mass in terms of carbon dioxide and water loss by evaporation caused by heat evolved during oxidation of organic carbon. The same condition was observed by Ajay and Azmi [12]. From Fig. 3, the graph show sthat the concentration of the total nitrogen is increased gradually week by week especially at week 8 for all reactors. Reactor X1 and X2 which the control compost for both commercial and research compost do not increased as much as other reactors due to the lack of nutrient in the reactor itself.The highest concentration demonstrated is at the last week for all reactors because the total nitrogen fixing bacteria might also have contributed to the increase in the total nitrogen in the later stage of composting [13].

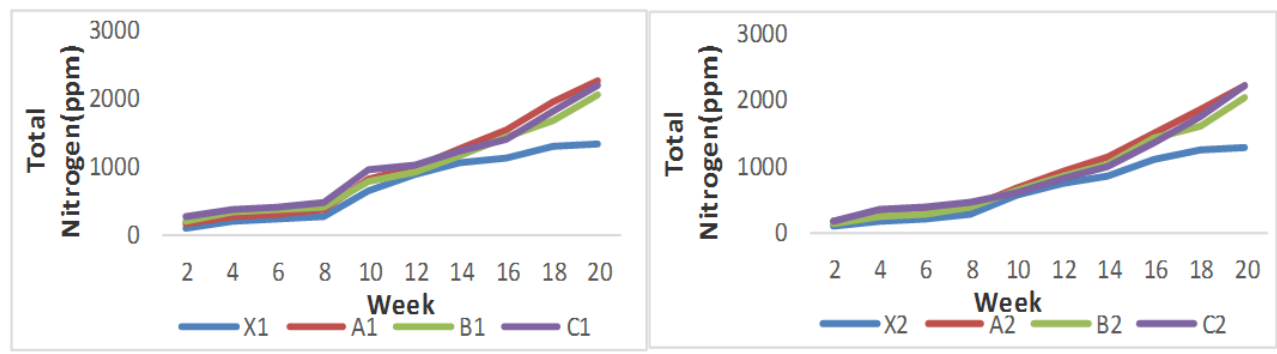

Fig.3. Total Nitrogen for all 8 reactors.

\subsection{Total Phosphorus Concentration}

In general, the trends of total phosphorus concentration in the reactors are slightly increase week by week. Total phosphorus content in Reactor B gradually increased during the composting process as shown in Fig. 4. The highest concentration was obtained in Reactor B2 and the lowest concentration was demonstrated in Reactor X1. This is because the increase in total phosphorus during composting was possibly caused by concentration effect arising from the higher rate of carbon loss that occurs when organic matter is decomposed[14]. 


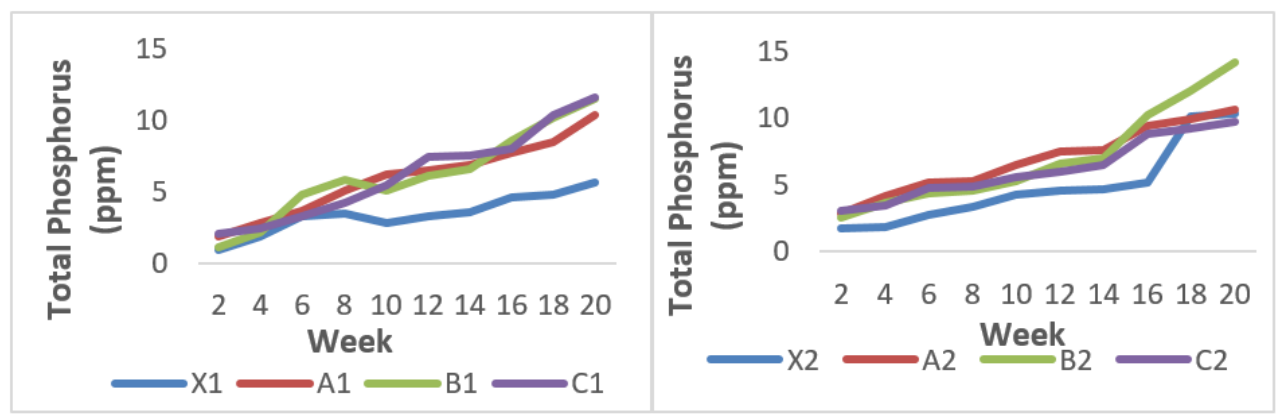

Fig.4. Total Phosphorus value for all 8 reactors.

\subsection{Potassium Concentration}

In this study, the potassium content is increased week by week but not constant. The highest concentration is in $\mathrm{C} 2$ which contain all the food waste in thi sstudy. From Fig. 5, the graph line show that the potassium value is not constantly increasing due to the interruption of microorganisms in the composta. Razzak [15] also claim that the values decreased and increased on a weekly basis and may be unstable due to the activity of microorganisms present in compost that also need nutrients. Therefore, the activity of microorganisms, which also need nutrients at certain times may cause the concentration of compost before maturity is not stable and declined. Most of the concentrations of all compost is growing very week.

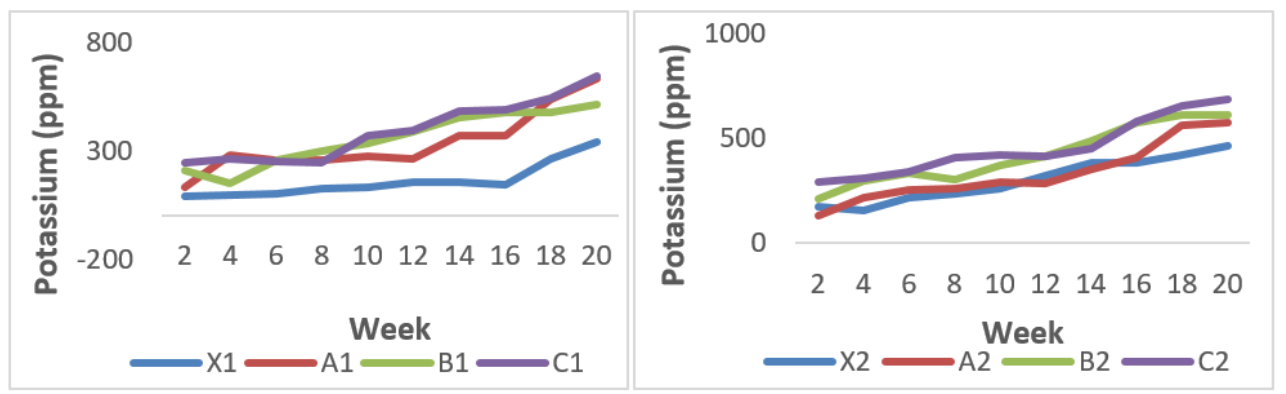

Fig.5. Potassium value for all 8 reactors.

\section{Conclusion}

In this composting study, temperature and $\mathrm{pH}$ values during the composting process were found to reach the level of the proposed range with $42^{\circ} \mathrm{C}$ to $45^{\circ} \mathrm{C}$ and 6.0 to 8.5 respectively.Total nitrogen value were $98 \mathrm{ppm}$ to $2268 \mathrm{ppm}$ for commercial compost and $84 \mathrm{ppm}$ to $2240 \mathrm{ppm}$ for research compost. As for total phosphorus the result obtained is $0.871 \mathrm{ppm}$ to $11.615 \mathrm{ppm}$ for commercial compost and $1.785 \mathrm{ppm}$ to $14.143 \mathrm{ppm}$ for research compost. On the other hand, result for potassium is $91.85 \mathrm{ppm}$ to $645.55 \mathrm{ppm}$ for commercial compost and $133.95 \mathrm{ppm}$ to $686.2 \mathrm{ppm}$ for research compost. Reactor C2showed the most effective composting process in this composting study. The concentration of total nitrogen increased gradually between each reactor by week. On the other hand, the concentration of total phosphorus and potassium increased weekly but fluctuated and research compost show higher concentration compare to commercial 
compost reactors. The different concentration indicated that the presence of different types of food waste added will differ the amount of NPK due to microbial activity. There is a potential for the compost in this study to be used for agricultural purpose since the nutrient performance which is the NPK is increasing week by week.

This paper was partly sponsored by the Centre for Graduate Studies UTHM.

\section{References}

[1] M.H. Kim and J.W. Kim, Comparison through a LCA evaluation analysis of food waste disposal options from the perspective of global warming and resource recovery. Science of the Total Environment, 408 (19), 3998-4006(2010)

[2] M.O. Saeed, M.N. Hassan and M.A. Mujeebu,Assessment of municipal solid waste generation and recycle materials potential in Kuala Lumpur, Malaysia. Waste Management, 29, 2209-2213,(2009)

[3] S.H. Lee, K.I. Choi, M. Osakoand D.J.I. Jong-In,Evaluation of environmental burdens caused by changes of food waste management systems in Seoul, Korea. Science of The Total Environment, 387 (1-3) 42-53,(2007)

[4] A.D. Knipe, The management of household food waste. Environmental Research and Consultancy. West Morden, United Kingdom, (2005)

[5] J.D. Wolna-Maruwka and A. Sawicka,Effect of temperature on the number of selected microorganism groups and enzymatic activityof sewage sludge composted with different additions in cybernetic.Agron. Res.,7(2), 875-890,(2009)

[6] E. Yenie,Kelembapan bahan dan suhu kompos sebagai parameter yang mempengaruhi proses pengomposan pada unit pengomposan rumbai. Jurusan Teknik Kimia Fakultas Teknik Universitas Riau, Pekanbaru, 28293, (2008)

[7] J. Peigné and P. Girardin,Environmental Impacts of Farm-Scale Composting Practices. Water, Air, Soil Pollut.,153(1-4), 45-68, (2004)

[8] C. Sundberg, D. Yu, I. Franke-Whittle, S. Kauppi, S. Smårs, H. Insam, M. Romantschukand H. Jönsson,Effects of $\mathrm{pH}$ and microbial composition on odour in food waste composting. Waste Manag., 33(1), 204-211, (2013)

[9] K. Nakasaki, H. Yaguchi, Y. Sasaki and H. Kubota, Effects of pH Control on Composting of Garbage. Waste Management Resource. 11(2), 117-125, (1993)

[10]C. Sundberg, S. Smårs and H. Jönsson,Low pH as an inhibiting factor in the transition from mesophilic to thermophilic phase in composting.Bioresour. Technol., 95(2), 145-150,(2004)

[11]L. Cooperband, Sustainable use of by products in land management. In Bartels, J.M., and W.A. Dick (eds.) Land application of agricultural, industrial and municipal by products. SSSA Book Series 6. p. 215- 235. Soil Science Society of America SSSA, Madison, Wisconsin, USA, (2000)

[12] S.K. Ajay and A.A. Kazmi, Rotary Drum Composting of Mixed Organic Waste based on Different $\mathrm{C} / \mathrm{N}$ Ratios. Proc. of the Int. Conf. on Sustainable Solid Waste Management, Chennai, India. 258-265,(2007)

[13]A. Abdul Kadir, S.N.M. Ismail and S.N. Jamaludin, Food Waste Composting Study from Makanan Ringan Mas. IOP Conf. Series: Materials Science and Engineering, 136, (2016) 
[14]C. Lin,A negative-pressure aeration system for composting food wastes.Bioresour. Technol., 99(16), 7651-7656, (2008)

[15]L.A. Razzak, Nutrition And Growth Of Bacteria, (2010) Retrieved on August 10, 2016 from http://www.uobabylon.edu.iq/eprints/publication_10_1062_180.pdf, 